\title{
The impact of insecurity and violence on the sales of Micro and Small companies in the city of Valle de Santiago, Guanajuato
}

\section{El impacto de la inseguridad y la violencia en las ventas de las Micro y Pequeñas empresas de la ciudad de Valle de Santiago, Guanajuato}

\author{
URIBE, María Guadalupe †*, BRAVO, Bibiano and MENDOZA, Patricia del Carmen \\ Universidad Tecnológica del Suroeste de Guanajuato (UTSOE)
}

ID $1^{\text {st }}$ Author: María Guadalupe, Uribe / ORC ID: 0000-0002-0093-5346, Researcher ID Thomson: S-8643-2018, CVU CONACYT ID: 743048

ID $1^{\text {st }}$ Coauthor: Bibiano Bravo / ORC ID: 0000-0002-4819-1323, Researcher ID Thomson: S-8658-2018, CVU CONACYT ID: 667470

ID $2^{\text {nd }}$ Coauthor: Patricia Del Carmen Mendoza / ORC ID: 0000-0002-7475-6703, Researcher ID Thomson: S-8805-2018, CVU CONACYT ID: 229872

DOI: 10.35429/JHRT.2019.16.5.1.8

Received: June 30, 2019; Accepted: December 20, 2019

\begin{abstract}
Nationwide, $63.0 \%$ of companies consider insecurity and crime as a major problem that affects them. (INEGI, 2018). On 2018 in Guanajuato, 93.3\% of companies considered it unsafe, with an increase of $38.3 \%$ over 2016 (INEGI, 2018). Their municipalities are no exception, in the case of Valle de Santiago, we seek to analyze the relationship between insecurity and violence with respect to annual sales of micro and small enterprises, the research is conducted through a cross-descriptive design, with a quantitative approach, through the questionnaire as an instrument, obtaining a sample of 550 companies. As a result of the research it was obtained that $90.7 \%$ of the directors of the micro and small companies express to be worried by the insecurity and violence that occurs in the municipality and therefore an impact is observed in the annual sales according to the calculation of the R square, obtaining 0.765 . Given the importance that micro and small enterprises have for the economic development of the municipality, the issue of insecurity and violence must be considered a priority due to its growing incidence, not only at the local level.
\end{abstract}

Insecurity, Violence, Sales

\section{Resumen}

A nivel nacional el $63.0 \%$ de las empresas considera la inseguridad y delincuencia como un problema importante que les afecta. (INEGI, 2018). En el año 2018, en Guanajuato el $93.3 \%$ de las empresas lo consideraron inseguro, con un incremento del $38.3 \%$ con respecto al 2016 (INEGI, 2018). Sus municipios no son la excepción, en el caso de Valle de Santiago, se busca analizar la relación que existe entre la inseguridad y violencia con respecto a las ventas anuales de las micro y pequeñas empresas; la investigación se realiza a través de un diseño transversal-descriptivo, con un enfoque cuantitativo, mediante el cuestionario como instrumento, obteniendo una muestra de 550 empresas. Como resultado de la investigación se obtuvo que el $90.7 \%$ de los directivos de las micro y pequeñas empresas manifiestan estar preocupados por la inseguridad y violencia que se vive en el municipio y por ende se observa un impacto en las ventas anuales según el cálculo del $\mathrm{R}$ cuadrado, obteniendo un 0.765 . Dada la importancia que las micro y pequeñas empresas tienen para el desarrollo económico del municipio, el tema de la inseguridad y la violencia debe ser considerado prioritario por su creciente incidencia no solo a nivel local.

Inseguridad, Violencia, Ventas

Citation: URIBE, María Guadalupe, BRAVO, Bibiano and MENDOZA, Patricia del Carmen. El impacto de la inseguridad y la violencia en las ventas de las Micro y Pequeñas empresas de la ciudad de Valle de Santiago, Guanajuato. Journal of Human Resources Training. 2019, 5-16: 1-8

\footnotetext{
*Correspondence to Author (mguribe@utsoe.edu.mx)

$\dagger$ Researcher contributing first Author
} 


\section{Introduction}

According to the World Health Organization (WHO), the term violence can be defined as the intentional use of physical force, threats against oneself, another person, a group or a community that has as a consequence or is very likely that result in trauma, psychological damage, developmental problems or death. (World Health Organization, 2019).

The issue of violence in the world is so ingrained that it can be considered part of the human condition, an almost unavoidable social problem that generates great repercussions and knows no borders, affects men and women, young and old and is present in homes, in the streets and in the works, 15 years ago more than 1.5 million people lost their lives violently and although these figures have been reduced, in the last 5 years globally, in part, due to the increase in the population, in Latin America it has been increasing since this region currently has the highest homicide rate derived from factors such as organized crime, inequality, unemployment, corruption and political instability.

In 2008, Mexico ranked 88th, currently occupies 140th place of 162 in the world peace ranking, considering it a dangerous country (Expansión, 2019), in the last 3 years the rates of violence in the country have increased from alarmingly since only 10 states have decreased or maintained rates of insecurity and violence, while in the remaining 22 they have increased, some of the main indicators of violence in Mexico is the homicide rate caused by organized crime, assaults and impunity.

In economic terms, in 2018 the impact of violence amounted to 5.16 billion pesos, which represents 24\% of the Gross Domestic Product (GDP), 10\% more compared to 2017, this implies that, if in Mexico it reduce the levels of violence to the equivalent of its 5 states with the best peace index, a dividend of 2.5 billion pesos per year equivalent to $11 \%$ of GDP would be generated.
In the state of Guanajuato, there was a general deterioration in its general rates of violence, but the most alarming was in homicides, registering a 127\% increase in 2018 (Institute for Economics and Peace, 2019). According to official data in 2017 from the National Institute of Statistics and Geography (INEGI), 34\% of the Guanajuato population was the victim of a crime, the most frequent being robbery or assault on the street or public transport, extortion and theft Total or partial vehicles in that order, on the other hand, $71 \%$ of the population stated that the most worrying problem is insecurity, which has caused changes in their behaviors, such as not allowing minor children to go outside or the use of jewelry, and in economic terms, the cost of household insecurity amounts to almost 11 million pesos in this federative entity. (INEGI, 2018).

Valle de Santiago is a municipality located southwest of the state of Guanajuato, its main economic activities are: agriculture, livestock, commerce and in recent years has opted for foreign investment in the industrial sector. In this municipality the increase in violence and insecurity has been caused mainly due to the theft of hydrocarbons, occupying the place 31 of 234 in the table of municipal violence in Mexico (Citizen Council for Public Security and Criminal Justice A.C., 2019).

The objective of this research is to analyze the relationship between insecurity and violence regarding the annual sales of micro and small businesses in Valle de Santiago, Guanajuato.

The main hypothesis planted considers that insecurity and violence is a factor that impacts the annual sales of micro and small businesses in Valle de Santiago, Guanajuato.

In this way, a study was carried out with a sample of 550 micro and small companies from the city of Valle de Santiago, Guanajuato; In the year 2018, through an investigation carried out through a transversal-descriptive design, with a quantitative approach, through the questionnaire as a research instrument. 
A positive result was obtained regarding the correlation between the factors studied, a situation that resembles the national and state landscape that most economic sectors in Mexico are going through, showing the urgency of generating strategies and mechanisms that contribute to reducing this problematic.

\section{Theoretical framework}

\section{Violence and business insecurity in Mexico}

The Royal Spanish Academy (RAE) defines the term insecurity as lack of security, which in turn means everything that is free of danger, harm or risk, or that is true, firm and inducible. Therefore, insecurity implies the existence of a danger, damage or risk. At a national level, $63.0 \%$ of economic units consider insecurity and crime as the most important problem that affects them, followed by the low purchasing power of the population with $35.4 \%$ and the lack of government support with 33.4 percent. (INEGI, 2018)

Entrepreneurs in Mexico have had to endure the increase in violence since 2006, reflecting aspects such as extortion and the payment of the so-called "right of floor", which especially affects entrepreneurs, especially those who have greater weaknesses such as they are small and medium-sized entrepreneurs and their businesses or SMEs (Carreón \& De la Cruz, 2012), resulting in an increase in insecurity that affects the capacity for business growth, as well as the activity of organized crime and with it actions against cartels of drugs, not only politically affects countries and their rulers, but above all impacts on the physical integrity, lifestyle and property of people (Magaloni, Díaz, \& Romero, 2014), in this way this type of criminal actions affects the current business environment to the point of causing a large number of entrepreneurs and entrepreneurs to be affected by bankruptcy, forced to close their organizations and in the case of Micro, Small and Medium Enterprises (MSMEs) trying to emigrate to safer places. The crime of business extortion has become a type of double tax obligation, where organized crime defies businessmen, who cannot rely on property rights included in the law, unable to achieve $\neg$ negotiation against the authority of the cartels, victims of the insecure environment, generating strategies that allow them to try to improve the situations that afflict them.
According to the study carried out by (Muñiz \& Ramírez, 2015), the types of crime or violence that entrepreneurs suffer are: 1) Violence against Small and Medium Enterprises (SMEs): The violent and criminal acts that covered this factor were: "Direct extortion of SMEs", "total or partial theft of materials", "destruction of property" and "robbery or assault" 2) Violence against entrepreneurs: The violent and criminal acts that made up this factor were "theft or assault (in the street or by public transport) ", physical aggression injuries ",“ kidnapping "and" murder".

It is very clear that by fostering an environment of trust and security among entrepreneurs and entrepreneurs, fostering an environment of business optimism, translating into higher levels of investment, which is reflected in job creation and thus an impact on economic growth. According to data from (COPARMEX, 2018), where the criminal victimization that employers face is identified, $57.9 \%$ of the members of the Employers' Confederation of the Mexican Republic (Coparmex) reported being a victim of the crime, identifying an increase in 4.9 points compared to the previous year (July 2018), in terms of the percentage of companies victims of crime by size; the micro reported $32.9 \%$, small businesses $51.4 \%$ and medium-sized companies $61.5 \%$. (COPARMEX, 2019).

\section{Impact of violence and business insecurity in Mexico}

The relationship between violence and development is complex, since economic growth is possible amid high rates of violence. But at the same time, precisely because of this, violence is more expensive than in countries with less dynamic economies and puts a stop to what, potentially, would be even greater growth, (Villamarín, 2011).

The average cost of crime per company is $\$ 66,031$ pesos per year, this represents a change of $14.3 \%$ compared to the average cost of 2015 that was $\$ 57.779$ pesos (COPARMEX, 2019). 
The crime imposes significant economic costs: loss of life, disruption of productive activities, less savings and investment, stress, and the focus of public and private efforts towards security activities, he says (Feliz, 2012), likewise the criminal activity reduces the product of the economy directly because it reduces the time allocated to production and indirectly reducing investment, and in its research where it refers it finds a negative, statistically robust relationship between economic growth and the homicide rate that is used as an indicator of criminal activity, as a reduction in the annual GDP per capita growth rate of $0.21 \%$ is observed, resulting in a "cumulative loss of $1.5 \%$ in the period 2003 2010 , equivalent to a third of the growth observed in the period "(Happy, 2012).

According to the National Survey of Victimization of Companies (ENVE) 2018, it is estimated that $33.7 \%$ of the economic units of the country were victims of a crime during 2017 , where $38.4 \%$ of the economic units of the commerce sector were victims of the crime, $30.6 \%$ of the industry sector and $29.3 \%$ of the services sector, of which $59.3 \%$ were large, $61.5 \%$ of medium-sized, $51.4 \%$ of small and $32.9 \%$ of micro and economic consequences in 2017, the total cost to consequence of insecurity and crime in economic units represents an amount of 55.8 billion pesos, that is, $0.86 \%$ of GDP with a monetary loss due to victimization in economic units, that is, those losses as a result of having been the victim of one or more crimes, amounted to 155.8 billion pesos. (INEGI, 2018).

The Institute for Economics and Peace (IEP) estimates that the economic impact of violence in Mexico in 2017 was 4.72 billion pesos (21\% of GDP), with an increase compared to 2016 of $15 \%$, equivalent to 634 billion pesos. And in 2016, $16 \%$ of managers reported that their companies invested more than $5 \%$ of their annual security operating budget; for 2017 , the percentage rose to $38 \%$, that is, it more than doubled, likewise, the main concern is the integrity of the employees (51.6\%), the security of their information $(36 \%)$ and cargo transport (35.7\%), crime (35.3\%) and the security of its facilities $(34.1 \%)$ (American Chamberof Commerce of Mexico, 2018).
For (Robles, Gustavo, Calderón, \& Magaloni, 2013), violence does not necessarily have a linear effect on economic performance. Below a certain threshold it is possible for companies to internalize their costs through payments of floor rights, theft, technology to increase their protection (such as cameras in trailers), rescues, bodyguard costs, among others. Under these conditions, violence could marginally affect both demand and labor supply. Smaller companies could stop operating causing labor demand to contract.

For (Soria, 2017), it is important to detect the most insecure states, which makes it possible to point out the federal entities in which it is necessary to prioritize strategies to limit violence and insecurity, and establish institutional improvement programs at both state and municipal levels.

\section{Violence and business insecurity in Guanajuato}

At the national level, $64.5 \%$ of the population 18 years of age and over considers insecurity and crime as the most important problem facing their federation today, followed by the price increase with $36.3 \%$ and unemployment with 33.2 percent. (INEGI, 2018). In the case of Guanajuato, $83 \%$ of the population considers it to be an unsafe state, committing a total of 1,141 , 848 crimes in 2017 , occupying eleventh place nationwide.

With respect to business violence, 3,347 companies affected by any crime were presented in 2017, especially in terms of extortion and theft or assault of merchandise, money, supplies or goods, with an average cost of crime per economic unit of 52,465 pesos. (INEGI, 2018).

Among the main crimes that are committed in Guanajuato companies is $11.8 \%$ for vandalism, in this way $93.3 \%$ of companies in 2018 consider it to be an unsafe federative entity, with an increase of $38.3 \%$ compared to 2016 ( INEGI, 2018), observing a high trend. It should not be forgotten that the state of Guanajuato is part of the main industrial corridor that is characterized by a strong attraction of investments, supporting the generation of jobs and with it economic development, for this reason the companies that are in this area generate an impact of development and growth; not forgetting that according to (American Chamberof Commerce of Mexico, 2018),

URIBE, María Guadalupe, BRAVO, Bibiano and MENDOZA, Patricia del Carmen. El impacto de la inseguridad y la violencia en las ventas de las Micro y Pequeñas empresas de la ciudad de Valle de Santiago, Guanajuato. Journal of Human Resources Training. 2019 
"The companies that we invest in Mexico recognize the great value and economic potential of the country. Macroeconomic and political stability, the demographic bonus and the human talent we have, among others, are strengths that generate confidence for investment. However, security and respect for the rule of law are great challenges for the competitiveness of Mexico from today. The operations of our companies and the confidence of investors are greatly affected by the high levels of insecurity, corruption and impunity, which deteriorate the social fabric and generate very high costs for our businesses".

Given the impact presented, concrete and effective strategies will have to be designed to reduce the rates of both violence and crime, as well as strengthen the security aspect of the entity and thus seek a coordinated action of all the organs of the social fabric with the objective of attacking insecurity as a complex problem, and with a multifactorial approach that helps maintain the path of development and economic growth that impacts the state and the country.

\section{Security and violence in Valle de Santiago}

Valle de Santiago is a municipality located to the southwest of the state of Guanajuato, with a population of 142672 inhabitants with an average age of 28 years; For every 100 people of productive age there are 56.1 in economic dependency age. The economically active population PEA is $41.6 \%$ and the non-active $57.9 \%$. (INEGI, 2015). The municipality has 5283 economic units which have as main turn agriculture, livestock, trade and in recent years has opted for foreign investment in the industrial sector, of these 5246 are micro and small companies, representing $99.3 \%$ (INEGI, 2016). Unfortunately, this municipality has also been hit by the wave of violence and insecurity that most of the state and the country is going through, in the specific case of this municipality and some neighbors such as: Salamanca, Irapuato, Pénjamo and Celaya, the increase in Violence and insecurity are due to the theft of hydrocarbons that are distributed through the Pemex pipelines to much of the country and from which the "huachicoleros" illegally extract fuel, this activity has increased the struggle of the cartels to take the control of this area for this profitable business.
According to the Citizen Council for Public Security and Criminal Justice (CCSPJP), in 2018 the municipality of Valle de Santiago ranked 31 of 234 in the table of municipal violence in Mexico with a total of 46.88 points compared to the first one Tecomán, Colima with 89.45 points, this in the crimes of homicides, kidnappings, rapes, injuries, robbery with violence and extortion, and took the place 24 of the 234 specifically in the crime of homicides with a rate of 61 per 100 thousand inhabitants (Citizen Council for Public Security and Criminal Justice AC, 2019).

It is important to mention that, regarding the subject addressed, there is a lack of reliable literature that provides information concerning the insecurity and violence that affects the business sector of the municipality of Valle de Santiago, being considered an area of opportunity within the research work.

\section{Methodology to be developed}

\section{Method}

The research is carried out through a crossdescriptive design, with a quantitative approach, using the questionnaire as a research tool. (Mendoza G. P., Uribe, Ramírez, \& Bravo, 2018).

\section{Instrument}

The questionnaire was designed to be selfadministered by the executives of micro and small companies formed for study in the first part by general characteristics with the item: annual sales and in the section valuation of the environment with the item: concern about insecurity and the violence. (Posada, Aguilar, \& Peña, 2016).

\section{Sample}

In order to have a statistically representative sample, the sample size was determined considering a $95 \%$ confidence level, a maximum error of $5 \%$ and the expected proportions were estimated at $50 \%$, from which a sample of 550 was obtained. micro and small businesses. 


\section{Hypothesis}

The main hypothesis planted considers that insecurity and violence is a factor that impacts the annual sales of micro and small businesses in Valle de Santiago, Guanajuato.

\section{Results}

\section{Sociodemographic characteristics of the participants}

Of the 550 entrepreneurs interviewed, $50.2 \%$ are women who are 43 years old on average; $73 \%$ of respondents are married. As for schooling, $6 \%$ of entrepreneurs did not have primary school completed; $15 \%$ studied primary school, $32 \%$ secondary school, $29 \%$ high school; $15 \%$ finished the degree, and only $3 \%$ have postgraduate studies. Regarding the time dedicated to the company, an average of 59 hours per week was obtained.

Table 1 shows the 10 activities that occur most frequently in the municipality of Valle de Santiago. Of the participating micro and small companies, $25 \%$ started operations between 2000 and 2009 and $57 \%$ in the period from 2010 to $2017 ; 18 \%$ arose before the year 2000 .

\begin{tabular}{|l|r|r|}
\hline \multicolumn{1}{|c|}{ Activities } & Quantity & Percentage \\
\hline $\begin{array}{l}\text { Retail sale in non-specialized } \\
\text { stores (such as miscellaneous) }\end{array}$ & 71 & 14.1 \\
\hline $\begin{array}{l}\text { Retail sale of food, beverages } \\
\text { and tobacco in specialized } \\
\text { stores (not restaurants) }\end{array}$ & 55 & 10.9 \\
\hline $\begin{array}{l}\text { Retail sale of other products in } \\
\text { specialized stores }\end{array}$ & 48 & 9.5 \\
\hline Food Products Processing & 39 & 7.7 \\
\hline Retail sale in stalls and markets & 32 & 6.3 \\
\hline $\begin{array}{l}\text { Retail sale of hardware, paints } \\
\text { and glass products in } \\
\text { specialized stores }\end{array}$ & 21 & 4.2 \\
\hline $\begin{array}{l}\text { Wholesale of clothing, } \\
\text { footwear and textiles }\end{array}$ & 20 & 4 \\
\hline $\begin{array}{l}\text { Retail sale of textile products in } \\
\text { specialized stores }\end{array}$ & 14 & 2.8 \\
\hline $\begin{array}{l}\text { Other personal service } \\
\text { activities }\end{array}$ & 14 & 2.8 \\
\hline $\begin{array}{l}\text { Wholesale of food, beverages } \\
\text { and tobacco }\end{array}$ & 12 & 2.4 \\
\hline
\end{tabular}

Table 1 Main activities of the municipality of Valle de Santiago

Source: (Mendoza G. P., Uribe, Ramírez, \& Bravo, 2018)
Once the analysis was carried out, it was determined that there is a moderate positive correlation of .609 between the study variables: annual sales and concern about insecurity and violence.

\begin{tabular}{|l|c|c|c|c|}
\hline \multicolumn{5}{|c|}{ Model Summary } \\
\hline Model & $\mathrm{R}$ & $\begin{array}{c}\mathrm{R} \\
\text { square }\end{array}$ & $\begin{array}{c}\text { R squared } \\
\text { squared }\end{array}$ & $\begin{array}{c}\text { Standard error of } \\
\text { the estimate }\end{array}$ \\
\hline 1 & $.875^{\mathrm{a}}$ & .765 & .765 & .494 \\
\hline
\end{tabular}

Table 2 Model Summary Source: self made

When making the adjustment, according to the calculation of the $\mathrm{R}$ square, a 0.765 was obtained. Which means that it is a model whose estimates are adjusted to the real variable, thus deducing that the annual sales of micro and small companies in the city of Valle de Santiago are affected by insecurity and violence in said municipality.

This is reflected in the perception of micro and small business managers, since $90.7 \%$ say they are worried about insecurity and violence.

\section{Conclusions}

Considering that micro and small enterprises represent $99.3 \%$ of the economic units in the municipality of Valle de Santiago and which contribute mostly to the generation of employment and its economic development, it is important to analyze any factors that threaten the permanence and Their growth in the market and one of these aspects is precisely insecurity and violence.

The problems of insecurity and violence in the municipality of Valle de Santiago were decisive actors in the closure of more than $80 \%$ of micro and small companies in 2017. (Mendoza P., Uribe, Bravo, \& Ramírez, 2017)

Therefore, the planted hypothesis is accepted since insecurity and violence impact the annual sales of micro and small businesses in the municipality.

Therefore, it is suggested to create strategic alliances between the business sector, society and government that help to combat insecurity and violence that surround the environment with the objective of better economic conditions and promote social welfare. 


\section{References}

American Chamberof Commerce of Mexico. (2018). Sondeo de Seguridad Empresarial 2018. México: Protectio: Seguridad logística. Obtenido de https://www.amcham.org.mx/sites/default/files/ publications/SondeoSeguridadEmpresarial2018. pdf

Carreón , G. J., \& De la Cruz, L. P. (2012). La lucha actual contra la delincuencia organizada en México. Barataria: revistacastellanomanchega de ciencias sociales, $n^{\circ}$ 14. Toledo, Asociación castellanomanchega de Sociología, 59-74.

Consejo Ciudadano para la Seguridad Pública y la Justicia Penal A.C. (05 de Febrero de 2019). www.seguridadjusticiaypaz.org.mx. Obtenido de http://seguridadjusticiaypaz.org.mx/files/Laviolencia-en-los-municipios-de-

Me\%CC\%81xico-2018.pdf

COPARMEX. (27 de Noviembre de 2018). Seguridad, combate a la corrupción y mejores empleos, temas prioritarios, advierten indicadores. Obtenido de https://coparmex.org.mx/seguridad-combate-ala-corrupcion-y-mejores-empleos-temasprioritarios-advierten-indicadores-dedatacoparmex/

COPARMEX. (Mayo- Junio de 2019). \#MásSeguridad . Obtenido de https://coparmex.org.mx:

https://coparmex.org.mx/wp-

content/uploads/2019/07/DataCPX_Boletin_M

$\% \mathrm{C} 3 \% \mathrm{~A} 1$ sSeguridad.pdf

Expansión. (agosto de 2019). Datosmacro.com. Obtenido de https://datosmacro.expansion.com/demografia/i ndice-paz-global/mexico

Feliz, R. (2012). Crimen y crecimiento económico en México. Los estados federales en el periodo 2003-2010. Las bases sociales del crimen organizado y la violencia en México, Centro de Investigación y Estudios en Seguridad (CIES), Ciudad de México, México., 221-245.

INEGI. (27 de agosto de 2015). Instituto Nacional de Estadística y Geografía. Obtenido de Información por entidad: http://www.inegi.org.mx/est/contenidos/proyect os/encuestas/hogares/especiales/ei2015/panora $\mathrm{ma} /$ presentacion.aspx
iNEGI. (agosto de 2016). Institutro Nacional de Estadística y Geografía. Obtenido de Directorio Estadístico Nacional de Unidades Económicas (DENUE):

http://www.beta.inegi.org.mx/app/mapa/denue/ cuantificar.aspx

INEGI. (24 de Octubre de 2018). Encuesta Nacional de Victimización de Empresas. Obtenido de https://www.inegi.org.mx: https://www.inegi.org.mx/contenidos/programa s/enve/2018/doc/enve_2018_presentacion_ejec utiva.pdf

INEGI. (25 de Septiembre de 2018). Encuesta nacional sobre victimización y percepción de seguridad pública (ENVIPE). Obtenido de https://www.inegi.org.mx:

https://www.inegi.org.mx/contenidos/programa s/envipe/2018/doc/envipe2018_presentacion_na cional.pdf

INEGI. (Septiembre de 2018). www.inegi.org.mx. Obtenido de https://www.inegi.org.mx/contenidos/programa s/envipe/2018/doc/envipe2018_gto.pdf

Institute for Economics and Peace. (abril d2019). Índice de Paz de Méxic. Obtenido de www.indicedepazmexico.org

Magaloni, B., Díaz, C. A., \& Romero, V. (2014). TheMexican War on Drugs: Crime and the Limits of Government Persuasion. . International Journal of Public Opinion Research(en prensa). Oxford, Oxford UnivPress. doi: 10.1093/ijpor/edu009.

Mendoza, G. P., Uribe, P. M., Ramírez, L. L., \& Bravo, A. B. (2018). Potencial Tecnológico de las Micro y Pequeñas Empresas Latinoamericanas a partir del Análisis Sistémico. Caso Valle de Santiago, Guanajuato. En d. S. Delgado, Potencial Tecnológico de las Micro y Pequeñas Empresas Latinoamericanas a partir del Análisis Sistémico. Tomo 1 (pág. 243). México: Fontamara.

Mendoza, P., Uribe, M., Bravo, B., \& Ramírez, L. (2017). Factores que determinan el cierre de la Micro y Pequeña Empresa, un análisis comparativo entre empresas activas en inactivas. Caso Valle de Santiago, Guanajuato. En A. N. Peña, R. O. Aguilar, \& V. R. Posada, Factores que determinan el cierre de la Micro y Pequeña Empresa (pág. 230). México: Pearson.

URIBE, María Guadalupe, BRAVO, Bibiano and MENDOZA, Patrici del Carmen. El impacto de la inseguridad y la violencia en las ventas de las Micro y Pequeñas empresas de la ciudad de Valle de Santiago, Guanajuato. Journal of Human Resources Training. 2019 
Muñiz, C., \& Ramírez, J. (2015). Los empresarios frente al narcotráfico en México.Tratamiento informativo de las reacciones empresariales ante situaciones de violencia e inseguridad. Estudios sobre el Mensaje Periodístico Vol. 21, Núm. 1, 437 - 453. doi:http://dx.doi.org/10.5209/rev_ESMP.2015.v 21.n1.49104

Organización Mundial de la Salud. (Julio de 2019). Organización Mundial de la Salud. Obtenido de

https://www.who.int/topics/violence/es/

Posada, V. R., Aguilar, R. O., \& Peña, A. N. (2016). Análisis Sistémico de la Micro y Pequeña Empresa en México. Mexico: Pearson Educación de México.

Robles, Gustavo, Calderón, G., \& Magaloni, B. (2013). Las consecuencias económicas de la violencia del narcotráfico en México. Documento de trabajo núm. IDB-WP-426, Banco Interamericano de Desarrollo, Washington, Estados Unidos, 49.

Soria, R. R. (2017). Impacto de la violencia e inseguridad en la competitividad de los estados mexicanos. Econ. soc. territ vol. 17 no. 54 Toluca may./ago. 2017. doi:http://dx.doi.org/10.22136/est002017802

Villamarín, G. A. (2011). Prevenir y calcular: una estimación de los costos de la violencia homicida en Colombia. Documentos del Centro de Recursos para el Análisis de Conflictos (Cerac), Bogotá, Colombia,. Obtenido de <www.cerac.org.co 